\title{
The Rockalliidae, a new family of Cainozoic Cytheracean Ostracoda
}

\author{
${ }^{1}$ ROBIN WHATLEY, ${ }^{2}$ HENNING UFFENORDE, ${ }^{1}$ CHRISTOPHER HARLOW, ${ }^{1}$ SIAN DOWNING \& 'KARIN KESLER \\ ${ }^{1}$ Geology Department, University College of Wales, Aberystwyth, U.K. \\ ${ }^{2}$ Niedersächsisches Landesamt für Bodenforschung, Stilleweg 2, \\ Postf. 510153, D-3000, Hannover 51, F.D.R.
}

\begin{abstract}
The Rockalliadae, a new family of Cytheracean Ostracoda, is erected based on Rockallia Whatley, Frame \& Whittaker, 1978 and an undescribed genus from the Tertiary of Argentinian Patagonia. Rockallia, hitherto monotypic, is augmented by the description herein of five new species: $R$. eocenica, $R$. vscripta and $R$. inceptiocelata from the Eocene, Neogene and Quaternary of the S.W. Pacific respectively and $R$. woutersi and $R$. sp. from the Oligocene and Miocene of N.W. Europe. The older species seem to have lived in relatively shallow water while the younger species are exclusively bathyal and abyssal. The genus is rediagnosed and its origins, evolutionary development and dispersal are discussed.
\end{abstract}

\section{INTRODUCTION}

As the trivial name of the type species (enigmatica) suggests, the genus Rockallia presents a number of problems with respect to its origins and affinities. When originally described by Whatley, Frame \& Whittaker (1978), only a single species was known. These authors faced something of a dilemma in assigning the original material to a supra-generic category and summed up the situation in the following way: "This new genus is difficult to assign with certainty to any group of Ostracoda. Although some 200 specimens have been encountered to date none have well preserved appendages although some have 'mummified' soft parts. The possession of four adductor scars in a vertical line would seem to indicate cytheracean affinities but the situation of these scars in a dorso-median position, the narrow and primitive inner lamella and the shape and outline are suggestive of the Platycopina. The genus is, on these grounds and in the absence of soft parts, tentatively referred to the latter suborder despite the fact that the overlap relationship of the valves militates against this."

The present authors are of the firm opinion that this tentative assignment to the Platycopina is quite incorrect and that the genus is a member of the superfamily Cytheracea of the Podocopina. The new material described in this paper and further study of the type species, allow us to be certain of this, the principal evidence being the possession of four adductor scars and a single frontal scar.

One of us (R.C.W.) has received written communications from a number of colleagues concerning the taxonomic status of the genus. For example, Dr. M.N. Gramm, who wrote in April and June 1979, gave good reasons why the genus was not a platycopid and Dr. J.W.
Neale (May 1979) was similarly unhappy with the original designation and suggested a possible morphological affinity with the Devonian genus Ponderodictya Coryell \& Malkin (1936) and a possibly closer relationship with the cytherid genus Cuneocythere Lienenklaus (1894). Dr. Karel Wouters (March 1979) suggested a close similarlity between Rockallia and Arcacythere Hornibrook (1953), a Tertiary to Recent New Zealand genus belonging to the Pectocytheridae.

However, in the light of the new species described herein, the authors are confident of the correctness of erecting a new cytherid family to accommodate Rockallia and an, as yet, undescribed genus from the Tertiary of Argentina. One of us (R.C.W.) has seen the latter in the collection of Lic. H.V. Valicenti. It is of Oligocene age and, in its left valve outline, is very similar to Rockallia although the right valve is somewhat dissimilar. In size, musculature and the nature of the hinge and inner lamella, the two genera are very similar although the undescribed genus (Pl. 2, figs. 17-19) has an eye, a structure which is lacking in all species of Rockallia. The ornament is also different. A description of this genus will be published elsewhere in due course.

The importance of the Argentinian material, however, is not merely in establishing the new family but, more importantly, when it is published it will suggest affinities to, and possible origins of, the Rockalliadae in the Cytherideidae, notably the Neocytherideinae. These affinities and possible origins are attested to also in Rockallia by its elongate shape and, among other features, the strongly developed fulcral point.

As Fig. 1 shows, Rockallia is now known to range from the Middle Eocene to the Recent. Although there are 


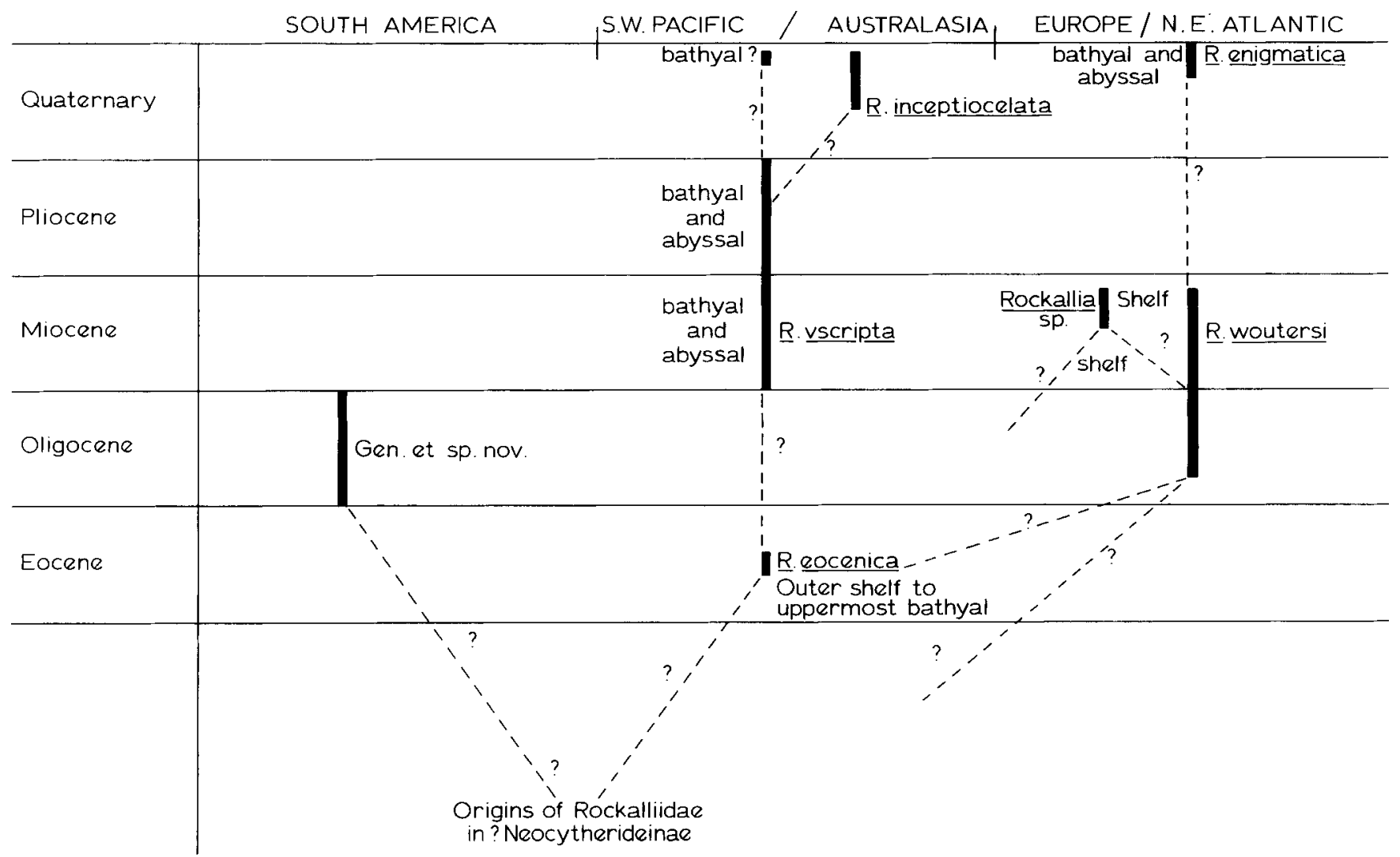

Fig.1. The Chronological, Geographical, and Palaeoecological distribution of the Rockalliidae.

many stratigraphical and geographical gaps in the fossil record of the genus, many of which will probably be filled in due course, it is, nonetheless, possible to suggest an outline evolutionary history of the genus.

Rockallia probably originated in either the late Cretaceous or early Tertiary, most likely in the S.W. Pacific/ Australian region. It may have descended direct from some neocytherideinid ancestor which it shares in common with the Argentinian Tertiary new genus mentioned above, or it may have descended from this postulated ancestor via the latter genus. The latter genus, on balance, retains more neocytherideinid characters than does Rockallia so that the second possibility seems the more likely one.

To date, the earliest known species of Rockallia is $R$. eocenica sp. nov. from the Middle Eocene of the site 207, S.W. Pacific. This site is on the southern end of the Lord Howe Rise (lat. $36^{\circ} 57.75^{\prime} \mathrm{S}$; long. $165^{\circ} 26.06^{\prime} \mathrm{E}$ ) at $1389 \mathrm{~m}$. water depth. The Middle Eocene palaeodepth was probably somewhat less than that of the present day because, although $R$. eocenica has been obtained from a pelagic ooze, the physiography of the Lord Howe Rise, surrounded as it is (and was) by deeper water, would preclude the introduction of clastic sediment and thus allow the calcareous ooze to be deposited at shelf depth without dilution. The shallowness of the type locality is further emphasized by the presence of a considerable number of sighted species among the ornate genera of the ostracod fauna and by the occurrence of Cytherelloidea Alexander (1929), as a dominant genus.

In stratigraphical terms, the next species of Rockallia known is $R$. woutersi sp. nov. from the Middle OligoceneUpper Miocene of continental N.W. Europe. In the Upper Miocene of Germany, this species occurs together with Rockallia sp. Both are probably outer shelf species which seem to have invaded possibly shallower water envionments in continental Europe during transgressive phases; this would have introduced oceanic Atlantic water masses into the North Sea basin.

The first unequivocal record of Rockallia from bathyal and abvssal depths is in the Middle Miocene of the S.W. Pacific and this species, $R$. vscripta sp. nov. ranges in this area into the Pleistocene. Interestingly, it has not been found further north in the Pacific nor at the three Neogene sites we have investigated in the Indian Ocean. Rockallia vscripta seems to have been largely replaced at the end of the Pliocene in this area by $R$. inceptiocelata sp. nov. although, as yet, we have only found this in the Quaternary at site 209 on the Queensland Plateau (lat. $15^{\circ} 56.19^{\prime} \mathrm{S}$; long. $152^{\circ} 11.27^{\prime}$ E) at a present day 
Table 1. General increase in size (length) of Rockallia species with time and invasion of deeper water environments.

\begin{tabular}{|c|c|c|c|c|c|}
\hline Ecology & & Maximum Size & Minimum Size & Mean Size & Stratigraphy \\
\hline \multirow{2}{*}{ 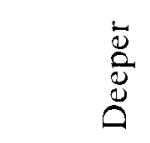 } & $R$. enigmatica & 0.59 & 0.54 & 0.56 & \multirow{2}{*}{ Quaternary } \\
\hline & $R$. inceptiocelata & 0.57 & 0.43 & 0.48 & \\
\hline \multirow{4}{*}{$\frac{\overline{0}}{\stackrel{3}{0}}$} & $R$. vscripta & 0.53 & 0.48 & 0.51 & \multirow{3}{*}{ Neogene } \\
\hline & R. woutersi & 0.45 & 0.41 & 0.43 & \\
\hline & $R . \mathrm{sp}$. & 0.40 & 0.39 & 0.40 & \\
\hline & R. eocenica & 0.40 & 0.37 & 0.38 & Palaeogene \\
\hline
\end{tabular}

water depth of $1428 \mathrm{~m}$, and at sites 207, south Lord Howe Rise (lat. $36^{\circ} 57.75^{\prime} \mathrm{S}$; long. $163^{\circ} 26.06^{\prime} \mathrm{E}$ ) water depth $1389 \mathrm{~m}$. and 208 , north Lord Howe Rise (lat. $26^{\circ}$ $06.61^{\prime} \mathrm{S}$; long. $161^{\circ} 13.27^{\prime}$ E) $1545 \mathrm{~m}$. This species, on the basis of its ornament, is probably a descendent of $R$. vscripta sp. nov.

Rockallia enigmatica bears a closer relationship to $R$. woutersi sp. nov. and to Rockallia sp. than it does to any of the Pacific species, although this relationship is by no means close. It does suggest, however, that since $R$. enigmatica appears to be virtually confined in bathyal and abyssal depths to a fairly restricted area of the N.E. Atlantic, that this species entered the deep sea in the European region and, therefore, that both the Pacific and European Palaeogene and early Neogene "shallow" water stocks gave rise, independently to species which entered the deep sea. This suggestion could, however, be nullified by the discovery of new material of the genus in pre-Quaternary deep water deposits in the Atlantic. The species of Rockallia increase fairly regularly in size with time from the smallest, $R$. eocenica sp. nov. to $R$. enigmatica as shown in table 1 .

\section{Systematic descriptions}

Order Podocopida Müller, 1894

Superfamily Cytheracea Baird, 1850

Family Rockalliidae fam. nov.

Genus Rockallia Whatley, Frame \& Whittaker, 1978

Type species Rockallia enigmatica Whatley, Frame \& Whittaker, 1978

Emended Diagnosis. A very small to medium sized cytherid ostracod. Subrectangular and elongate in lateral vicw; subelliptical in dorsal view, widest in posterior third, tapering regularly anteriorly. Valves of different shape, left valve with straight to gently convex ventral margin, right valve with distinct keel-like projection just posterior to mid-point ventrally and with more or less pronounced mid-ventral incurvature. Dorsal margin straight; end margins never caudate, usually subrounded to truncated. Ornament coarsely reticulate with variable development of ribs and fossae, sometimes with micropapillae on the ribs; sometimes with partly celate fossae. Adductor and frontal muscle scar nodes often present externally. Blind. Normal pores open, few and situated on pore conuli, very constant in position within the genus. Two prominent pore conuli occur close to the anterior and posterior margins. Inner lamella narrow to medium in width, small vestibule at each end, selvage strong, peripheral to subperipheral. Hinge lophodont. Adductor scars a vertical row of 4 , often interdigitating, situated medianly and more dorsally than in other cytherids; single large, subreniform frontal scar. A large triangular to sub-crescentic fulcral point occurs almost dorsal to the adductor scars. Sexually dimorphic; males more elongate than females and less inflated.

All the type and figured material referred to in this study is deposited in the collections of the British Museum (Natural History), to which the registration numbers apply.

Rockallia enigmatica Whatley, Frame \& Whittaker, 1978 (PI. 1, figs. 1, 4)

1978 Rockallia enigmatica sp. nov. Whatley, Frame \& Whittaker, 137-144, pl. 5. 138, 140.142. 144. text fig. 1 .

1979 Indet. gen. 3. Ducasse \& Peypouquet, figs. 6, 7, pl. 5 , fig. 9.

Remarks. The species was first described from the Holocene and Recent of the Rockall Trough in the N.E. Atlantic in pelagic oozes of water depths from 1040 to $4000 \mathrm{~m}$. Subsequently it has been illustrated (as indet. gen. 3) by Ducasse \& Peypouquet (1979) from the Quaternary of the southwest margin of the Rockall 
Plateau (D.S.D.P. sites 405 and 405) from abyssal and bathyal depths.

Two postgraduate students at Aberystwyth have encountered additional material of the species. H. Davies has found Recent and Quaternary material in the general areas of the Porcupine Sea Bight and Rockall in moderate numbers, although it was never common in any sample. He has raised the minimum depth for the occurrence of this species to $119 \mathrm{~m}$, by finding a single specimen in a sample taken some $70 \mathrm{~km}$ west of Colonsay in the Inner Hebrides (lat. $56^{\circ} 7.65^{\prime} \mathrm{N}$; long. $7^{\circ} 30.35^{\prime} \mathrm{W}$ ). None of his material found was living.

R. W. Jones has encountered $R$. enigmatica commonly in late Quaternary to Recent cores in the N.E. Atlantic between $45^{\circ} \mathrm{N}$ and $61^{\circ} \mathrm{N}$ and between present day water depths of 938 and $4566 \mathrm{~m}$. It is not usually abundant in any sample although occasionally it is a dominant species as, for example, in one sample at $1678 \mathrm{~m}$. north of the Lousy Bank. Most of the samples in this area are of pelagic ooze.

$R$. enigmatic differs from the other species of the genus described below, in that the vertical component of the ribs, which form its reticulation, dominate and radiate rather regularly from the mid-dorsal region. The faint secondary papillate ridges on the ribs anteriorly and posteriorly are very well developed on this species. Also, the smooth nodes which externally denote the position of the adductor and frontal scars are particularly strongly developed in the female right valve. $R$. enigmatica is the largest of the species known to date.

Although several hundred specimens now exist in U.C.W. collections of this, the only extant, species, none have been recovered with well preserved soft parts, although some specimens have "mummified" appendages. This is unfortunate, since a knowledge of the morphology of the appendages would probably be of considerable value in better understanding the taxonomic relationships of the genus.
Rockallia eocenica sp. nov.

(Pl. 1, figs. 2, 3, 5-10)

Derivation of name. Greek, with reference to the fact that, at the time of writing, this is the only known species of the genus from the Eocene.

Diagnosis. A very small to small species of Rockallia with pronounced sexual dimorphism and characterized by a deeply incised arcuate sulcus posteriorly which separates the elevated posterolateral surface from the less elevated posterior rim.

Holotype. Female RV, OS 12105.

Material. 36 adult and $\mathrm{A}-1$ juvenile valves.

Locality and horizon. D.S.D.P. Site 207, hole 207A, south Lord Howe Rise, Lat. $36^{\circ} 57.75^{\prime} \mathrm{S}$; Long. $165^{\circ}$ $26.06^{\prime}$ E. Present day water depth $1389 \mathrm{~m} .147 \mathrm{~m}$. below sea floor. Middle Eocene (core 11, section 4), Bortonian Stage, foraminiferal and nannofossil ooze.

Description. Very small to small. Elongate and subrectangular in lateral view. Anterior margin asymmetrically rounded in both valves with extremity below mid-height. Posterior margin broadly rounded in left valve with extremity just above mid-height; in right valve more acuminate. Dorsal margin long and straight; somewhat upturned posteriorly. Posterior cardinal angle pronounced in both valves. Ventral margin of left valve straight; right valve with slight oral concavity and distinct keel-like process just behind centre. Length a little more than twice the height. Maximum length at mid-height; maximum height between the cardinal angles in left valve, through "keel" in right valve; maximum width in posterior third. Ornament strongly reticulate. Around, and subparallel to, the free margins extend a pair of subparallel ribs which contain oval to rectangular fossae, the long axes of which are parallel to the margins. Posteriorly, these ribs are separated from the elevated lateral surface by a deep arcuate sulcus bearing polygonal fossae. Of the ribs which form the reticulation on the remainder of the lateral surface those which form the vertical component

\section{Explanation of Plate 1}

All figures are $x 100$ unless otherwise specified

Figs. 1, 4 Rockallia enigmatica Whatley, Frame \& Whittaker: fig. 1, \& RV, OS 12103. ext. lat., Late Quaternary core N.E. Atlantic, approx. lat. $61^{\circ} \mathrm{N}$, long. $13^{\circ} \mathrm{W}$; fig. 4, $9 \mathrm{LV}$, OS 12104 , ext. lat. as above.

Figs. 2, 3, 5-10 Rockallia eocenica sp. nov.: fig. 2, holotype 9 RV, OS 12105, dors.; fig. 3, o RV, OS 12106. dors.; fig. 5 , o LV, OS 12107, ext. lat,; fig. 6, \& RV, OS 12108, ext. lat.; fig. 7, \& RV, OS 12105, ext. lat.; fig. 8, ó LV, OS 12109 , ext. lat.; fig. 9, ơ RV, OS 12110 , ext. lat.; fig. 10, of RV, OS 12111, ext. lat.

Figs. 11-20 Rockallia inceptiocelata sp. nov.; figs. 11, 12, holotype $\$$ LV. OS 12112, ext. lat. and dors.; fig. 13, ot RV, OS 12113, dors.; fig. 14, o LV, OS 12114, int. lat., fig. 15, o RV, OS 12113, ext. lat.; fig. 16, q RV, OS 12115, ext. lat.; fig. 17, o LV, OS 12114, detail of adductors and frontal scar (approx. x 500); fig. 18, $\$ \mathrm{LV}$, OS 12116, ext. lat. (possibly a post-maturation moult); figs. 19, 20, same specimen, details of dorsomedian and ventrolateral ext. surfaces (approx. x 120 and 380). 


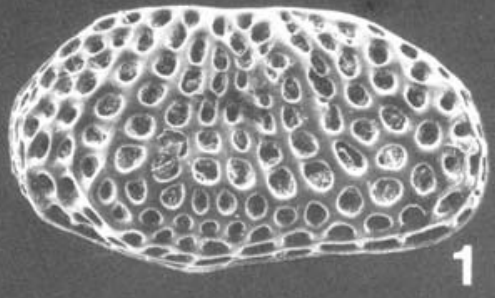

\section{PLATE 1}
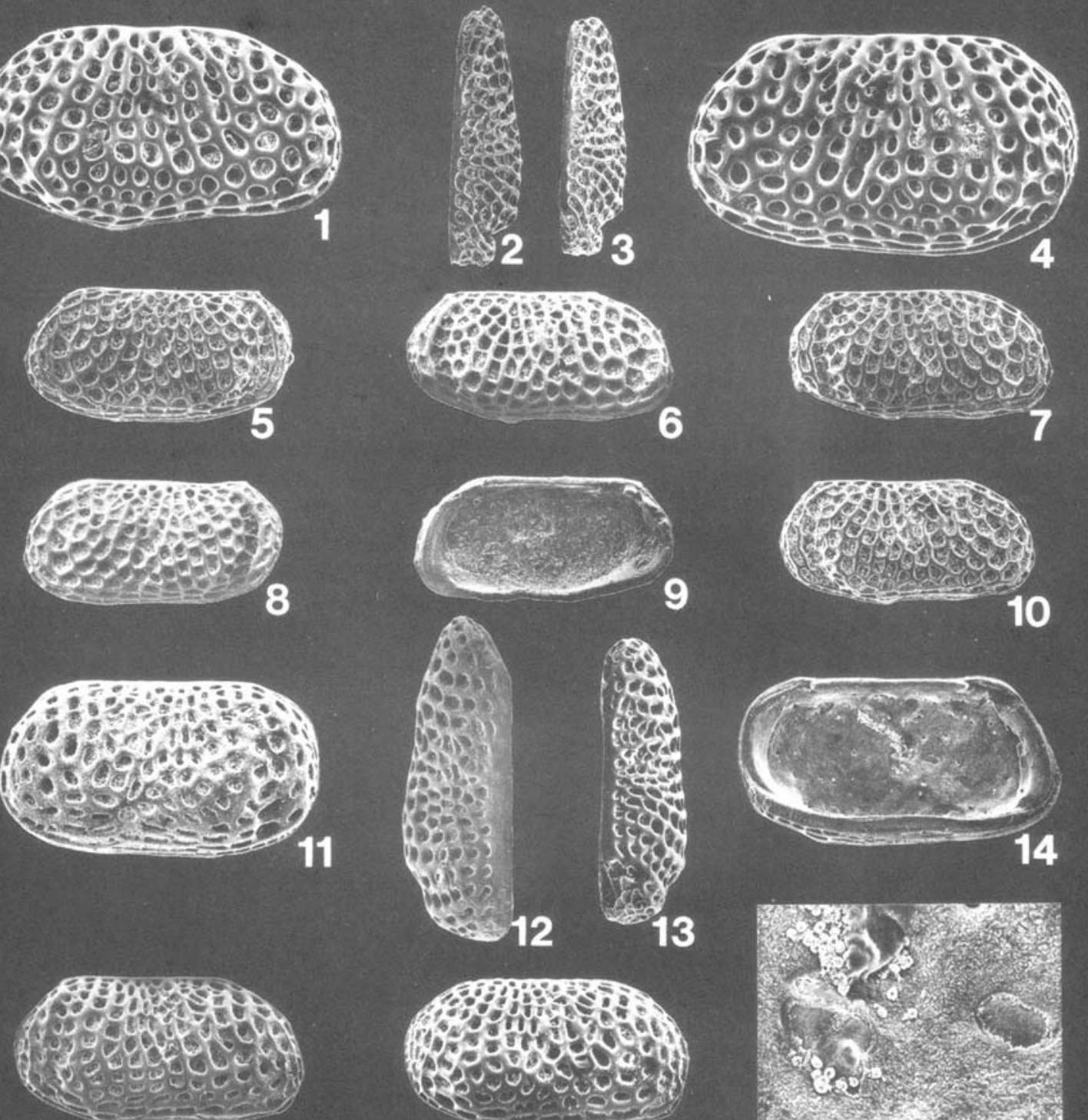

15
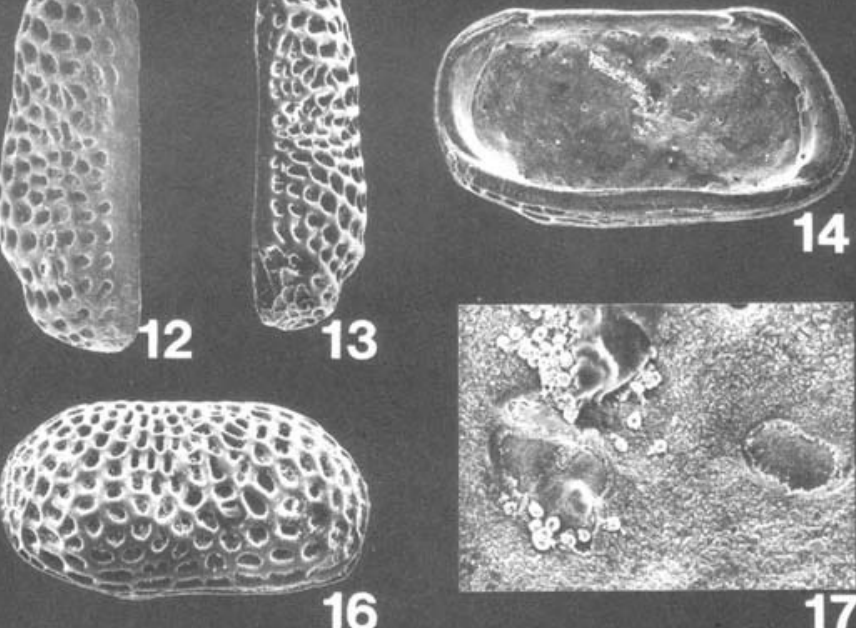

16
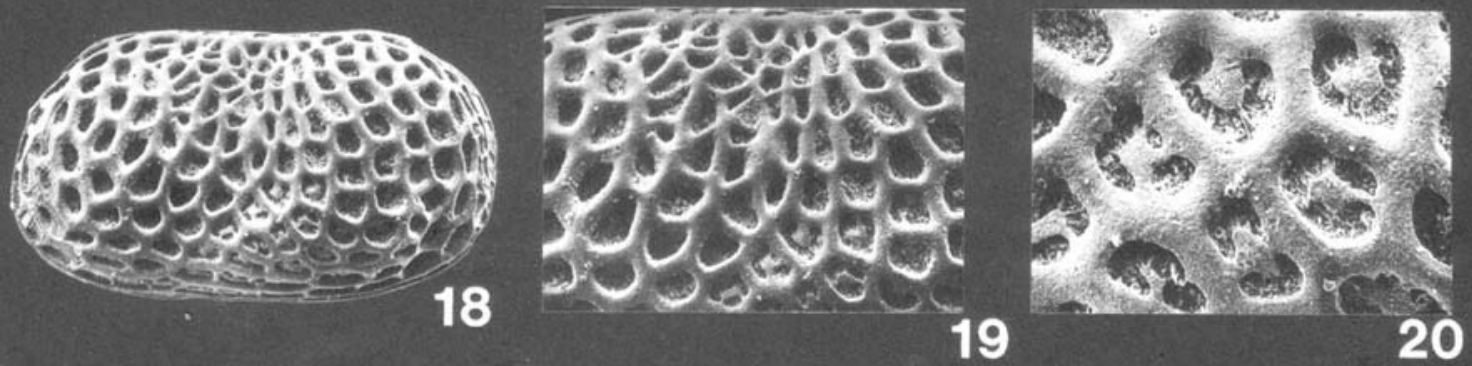
and which radiate from the dorsal margin, tend to dominate. The ribs are rather narrow and rounded in profile. The fossae tend to increase in size distally from the centre and also to become less angular in outline. The adductor muscle scar node is situated dorsomedianly and is well marked, it is enclosed by a sub-vertically aligned "V"' shaped rib rather like that in $R$. vscripta sp. nov. but much less well defined. The frontal muscle scar node is present but indistinct. Normal pores rather few, situated on the ribs and apparently simple. Their distribution is as in other species of the genus. The anterior and posterior pore conuli characteristic of the genus are present but while strongly developed posteriorly they are somewhat subdued anteriorly. Internal features as for genus. Muscle scars situated dorsomedianly, largely obscured. Sexual dimorphism pronounced; males more elongate than females.

$\begin{array}{cll}\text { Dimensions. (mm) } & \text { Length } & \text { Height } \\ \text { Holotype o RV, OS 12105 } & 0.39 & 0.19 \\ \text { Paratype \& LV, OS } 12110 & 0.37 & 0.18 \\ \text { Paratype \& LV, OS 12106 } & 0.38 & 0.19 \\ \text { Paratype क RV, OS 12108 } & 0.40 & 0.19 \\ \text { Paratype o LV, OS 12107 } & 0.38 & 0.18 \\ \text { Paratype of RV, OS 12111 } & 0.39 & 0.19 \\ \text { Paratype of LV, OS 12109 } & 0.39 & 0.20\end{array}$

Remarks. This species differs from all the other known species of Rockallia mainly by virtue of its small size and possession of the arcuate posterior sulcus. The present restriction of this carliest known species of the genus to a single sample of Middle Eocene age at site 207 is due to the fact that our studies of Palaeogene Ostracoda in this region have only just begun. (November 1981). The species has not, however, been recovered from Lower Eocene samples at the same site.

Distribution. At present known only from site 207A, sample 11/4, Middle Eocene.

\section{Rockallia inceptiocelata sp. nov.}

(Pl. 1, figs. 11-20)

Derivation of name. Latin, with reference to the incipient infilling of the fossae in the mid ventrolateral area of the carapace of this species.

Diagnosis. Rockallia characterized by the development of "keyhole" celation within the fossae of the mid ventrolateral region and by the irregular nature of the fossae in this region and, more particularly, in the mid dorsolateral area. In this latter area the fossae are strongly drawn out into a vertical alignment. The most ventral of the adductor scars bears a strong sub-conical boss.

Holotype. Female LV, OS 12112.

Material. 18 adults and juveniles.

Locality and horizon. D.S.D.P. site 207, South Lord Howe Rise, Lat $36^{\circ} 57.75^{\prime}$ S ; Long. $163^{\circ} 26.06^{\prime}$ E. Present day water depth $1389 \mathrm{~m} .8 .5 \mathrm{~m}$. below the sea floor, core
2, section 2, zone NN 19. Pleistocene. Foraminifera rich nannofossil ooze.

Description. Small to medium size. Subrectangular in lateral view. Asymmetrically semi-elliptical in dorsal vicw. Anterior margin regularly rounded in right valve; somewhat truncated in left valve. Posterior margin subtruncated in left valve; bluntly rounded in female right valve; more pointed in male right valve. Dorsal margin straight in right valve, in which male has marked posterodorsal cardinal angle; medianly concave in left valve. Ventral margin slightly biconvex about shallow median concavity in left valve; right valve with keel-like projection posterior of centre. Length approximately twice the height. Maximum length at, or just below mid-height with anterior extremity below mid-height except in female right valve where it is at mid-height; posterior extremity at mid-height. Maximum height at anterior angle in left valve; through posteroventral keel in right valve. Maximum width in posterior quarter. Ornament strongly and irregularly reticulate and somewhat variable in expression between individuals although the basic distribution of the fossae is constant throughout the species. The fossae are parallel, and aligned with, the free margins. Also, around the periphery, the interfossal ribs parallel the margins. In the mid dorso-lateral region the fossal pattern is very confused and irregular and three sub-vertical rows of fossae, which extend from the dorsal margin just behind centre, are strongly drawn out along vertical axes. This vertical alignment persists to the area immediately posterior to the adductor node. In general the fossae increase in size towards the periphery. In the mid posterolateral area they are more rounded in profile than elsewhere. The costae vary somewhat in thickness between individuals. Adductor and frontal scar nodes well marked. Mid ventrolaterally, the fossae exhibit "keyhole" celation. Normal pore canals few, wellspaced; pores simple and situated on the costae. Two pore conuli occur adjacent to the anterior margin and two similar conuli subadjacent to the posterior margin. Inner lamella rather wide for the genus. Radial pore canals few, simple and straight. Hinge lophodont with locellate gutter-like accommodation groove above median element of left valve, which latter is somewhat expanded distally. Adductor muscle scars small and dorsomedian in position; they comprise a vertical row of 4 scars, the median two of which interlock and the ventral of which bears a strong conical boss. Dorsal and slightly anterior to the dorsal adductor scar is a strong sub-oval fulcral point. The front scar is typical of the genus. Males are more elongate and less tumid posteriorly than females.

$\begin{array}{cll}\text { Dimensions. (mm) } & \text { Length } & \text { Height } \\ \text { Holotype \& LV, OS } 12112 & 0.48 & 0.26 \\ \text { Paratype of RV, OS } 12113 & 0.44 & 0.22 \\ \text { Paratype of LV, OS 12114 } & 0.48 & 0.24 \\ \text { Paratype o LV, OS 12116 } & 0.57 & 0.32 \\ \text { Paratype क RV, OS } 12115 & 0.43 & 0.23\end{array}$


From respectively:

Site $207 / 2 / 2$

Site $208 / 3 / 3$

Site $207 / 1 / 2$

Site $207 / 2 / 2$

Site $208 / 3 / 3$

Remarks. The species differs from the other species of the genus described herein by virtue of the "keyhole" celation of the fossae in the mid ventrolateral region and in strongly vertically aligned fossae which occur mid dorsolaterally. It is very likely that, since the species has been found in late Pleistocene sediments in the Australasian region, it still lives there today. The single very large specimen (Paratype, female left valve, OS 12116) from site 207, is thought to be a post maturation moult since the smaller type specimens all exhibit adult characters internally.

Distribution. At present known only from the type locality and from the Pleistocene of site $209(2 / 2,2 / 6$ and 1/5), Queensland Plateau, Lat. $15^{\circ} 56.19^{\prime}$ S; Long. $152^{\circ} 11.27^{\prime}$ E. Present day water depth $1428 \mathrm{~m}$. and from the Pleistocene of site 208 (3/3), North Lord Howe Rise, Lat. $26^{\circ} 06.61^{\prime} \mathrm{S}$; Long. $161^{\circ} 13.27^{\prime}$ E., present day water depth $1545 \mathrm{~m}$.

\section{Rockallia vscripta sp. nov.} (PI. 2, figs. 1-6, 8)

Derivation of name. Latin, with reference to the " $V$ "shaped rib enclosing the adductor muscle scar in this species.

Diagnosis. Rockallia characterized by the absence of vertical alignment of the ribs over the centre of the valves, by the presence of a " $V$ " shaped, obliquely aligned rib, open dorsally, enclosing the aductor muscle scars, the external reflection of which is marked by a smooth node and by the strong development of paired ribs peripheral and subparallel to the posterior margin.

Holotype. Female left valve, OS 12117.

Material. 76 adult and juvenile valves.

Locality and horizon. D.S.D.P. site 207, hole 207A, south Lord Howe Rise, lat. $36^{\circ} 57.75^{\prime} \mathrm{S}$; long. $165^{\circ}$ $26.06^{\prime}$ E. Present day water depth $1389 \mathrm{~m} .124 \mathrm{~m}$. below sea floor. Middle Miocene Clifdenian Stage, calcareous nannofossil zone NN 5; white to pale yellow nannofossil bearing foraminiferal ooze.

Description. Small to medium size. Subrectangular in lateral view. Anterior margin broadly rounded in left valve, more asymmetrical in right valve with ventral apex. Posterior margin broadly and regularly rounded in left valve, bluntly pointed with apex above mid-height in right. Dorsal margin of both valves straight or very slightly concave between pronounced cardinal angles. Ventral margins straight to gently convex in left valve; that of right valve with distinct keel-like projection just behind centre and with slight oral concavity. Length approximately twice the height. Maximum length at or just below mid-height. Maximum height in anterior quarter of left valve; through ventral "keel" in right. Ornament strongly reticulate. Around, and subparallel to, the free margins extend a pair of strong ribs with deep ovai to subrectangular fossae. These ribs are particularly strongly developed posteriorly and ventrally. Over the remainder of the lateral surface, the fossae generally increase in size away from the centre and are smallest mid-dorsally. Over much of the surface the horizontal component of the ribs forming the recticulum are as strong as those of the vertical components. The ribs are smooth except anteriorly and dorsally where they may bear faint papillate ridges parallel to their long axes. However, a strong sub-vertically aligned " $V$ " shaped rib, open dorsally, encloses the adductor scars, the external reflection of which is marked by a smooth node situated somewhat above mid-point. The frontal scar is marked by the presence of a much less well developed node. Normal pore canals rather few and well-spaced; they are apparently simple and are situated on the top, or the flanks of the ribs. A prominent pore conulus occurs near mid-point. Two prominent pore conuli occur close to the anterior margin and two similar pore conuli occur posteriorly but at a little distance from the posterior margin. Inner lamella of medium width; widest at the end margins where narrow crescentic vestibules occur. Selvage well developed, broad and subperipheral. Radial pore canals simple, straight; 6-7 anteriorly, 5-6 posteriorly. Hinge lophodont. In the right valve the terminal elements are very weak, smooth knob-like teeth and the median element is a shallow smooth groove open to the interior. Complementary structures occur in the left valve hinge, above the median element of which is a narrow "gutter"-like accommodation groove. Adductor muscle scars small and situated above mid-height. They comprise a verticle row of 4 scars, the median two of which interlock. The frontal scar is relatively large and "heart"-shaped. Dorsal and slightly anterior to the adductors is a large sub-ovate fulcral point. Sexual dimorphism not particularly marked; males somewhat more elongate than females.

$\begin{array}{cll}\text { Dimensions (mm) } & \text { Length } & \text { Height } \\ \text { Holotype \& LV, OS } 12117 & 0.50 & 0.26 \\ \text { Paratype \& RV, OS } 12118 & 0.50 & 0.26 \\ \text { Paratype \& RV, OS } 12119 & 0.48 & 0.26 \\ \text { Paratype of RV, OS } 12120 & 0.53 & 0.26\end{array}$

From respectively: Site 207 Middle Miocene

Site 209/6/1 Middle Miocene Site 207/9/3 Middle Miocene Same sample as holotype

Pliocene specimens are larger than those from the Miocene; mean length 0.53 , mean height $0.28 .5 \mathrm{~mm}$. The single Pleistocene specimen is smaller, however: length 0.46 , height 0.23 . 
Remarks. This species differs from other members of the genus in the virtual absence of vertical alignment of the ribs, in its posession of the " $V$ "-shaped rib enclosing the adductor scar node and in its possession of two strong ribs subparallel to the posterior margin. It does not seem to be as closely related to $R$. enigmatica or $R$. woutersi as these two species are to each other. On the basis of similarities in ornament, it is probable that $R$. vscripta was derived from $R$. eocenica and also that it is ancestral to $R$. inceptiocelata. The single specimen from the Pleistocene of site 281 (Pl. 2, fig. 6) which is at present tentatively assigned to $R$. vscripta may, with the acquisition of more material, prove to belong to a distinct species.

Distribution. The species has been recovered from Miocene sediments at D.S.D.P. sites 56, 62, 288, 208, 207, and 209 and from the Pliocene of D.S.D.P. sites 64, 207, 208, 288 and 289. All these sites are in the Western Pacific and are between lat. $8^{\circ} 22^{\prime} \mathrm{N}$ and lat. $36^{\circ} 57^{\prime} \mathrm{S}$ and between long. $141^{\circ} 56^{\prime} \mathrm{E}$ and long. $165^{\circ} 26^{\prime} \mathrm{E}$. The species ranges throughout the Miocene and Pliocene. The present day water depths range between $1389 \mathrm{~m}$ and $3000 \mathrm{~m}$. Sites with strata of equivalent age further north in the Pacific, and Neogene samples from three sites in the Indian Ocean, have failed to yield the species. One specimen, tentatively assigned to this species has been recovered from D.S.D.P. site 281 at lat. $47^{\circ}$ $59.84^{\prime} \mathrm{S}$; long. $147^{\circ} 45.85^{\prime} \mathrm{E}$. in the late Pleistocene at a present day water depth of $1591 \mathrm{~m}$.

Rockallia woutersi sp. nov.

(Pl. 2, figs. 7, 9, 10-14, 16)

1980 Rockallia sp. 1. Uffenorde, table 1, p. 307, table 3 , p. 313.

1981 Rockallia sp. 1. Uffenorde, text - fig. 2.
Derivation of name. In honour of Dr. Karel Wouters who provided specimens of this species and in recognition of his signal contribution to our understanding of European Neogene Ostracoda.

Diagnosis. Rockallia characterized by both end margins being asymmetrically rounded and by an ornament in which the elevated areas are relatively wide and the fossae correspondingly small and usually subrounded. A pair of large and internally complex pore conuli occur near the posterior margin.

Holotype. Male RV, OS 12123.

Material. 17 valves and carapaces.

Locality and horizon. Deep boring at Vaale, N.W. Germany; 263-264 m. below surface, "Septarienton", Rupelian, Middle Oligocene.

Description. Small in size, subrectangular, elongate in lateral aspect. Asymmetrically ellipsoidal in dorsal view. Anterior margin asymmetrically rounded in both valves with, in the left valve and female right valve, a slightly convex anterodorsal slope and in the male right valve a more convex anterodorsal slope; anteroventral margin well rounded; extremity below mid-height. Posterior margin broadly and regularly rounded in female, bluntly acuminate in male; extremity at mid-height. Dorsal margin straight in both valves with well marked cardinal angles, particularly the posterior of the male. Ventral margin gently convex in left valve; biconvex in right with shallow concavity and distinct keel-like process just behind mid-ventral. Maximum length just below midheight; maximum height just behind centre in both valves; maximum width in posterior third. Ornament strongly reticulate with wide, smooth (except anteriorly and posteriorly where delicate papillate ridges occur) interpunctate elevated areas and rather small (for the genus), deeply excavated circular to ovate punctae, the solae of which are both smooth and secondarily reticulate.

\section{Explanation of Plate 2}

All figures are $x 100$ unless otherwise specified

Figs. 1-6, 8 Rockallia vscripta sp. nov.: fig. 1, $q$ LV, OS 12118, ext. lat.; fig. 2, of RV, OS12120, ext. lat.; fig. 3, o RV, OS 12119. ext. lat.; fig. 4, holotype $\$ \mathrm{LV}$, OS 12117, ext. lat.; fig. 5, ơ RV, OS 12120, int.; fig. 6, \& RV, OS 12121, ext. lat. All from site 281/2/1, late Pleistocene. Fig. 8, 9 LV, OS 12122, detail of central muscle scars (approx. $x 400$ ), site 208/5/6 Zone N20, Upper Pliocene.

Figs. 7, 9-14, 16 Rockallia woutersi sp. nov.: figs. 7, 9, holotype ơ RV, OS 12123, int. and ext. lat.; fig. 10, \$ LV, OS 12124, ext. lat.; fig. 11-14, 9 car., OS 12125: fig. 11, dors.; fig. 12, post. (x 200); fig. 13, right lat.; fig. 14, detail of post. pore conulus (approx. x 1730); fig. 16, holotype, of RV, OS 12123, detail of central muscle scars (approx. $\mathrm{x} 400)$.

Fig. 15 Rockallia sp. 9 LV, OS 12126, ext. lat.

Figs. 17-19 Gen. et sp. nov. Oligocene Santa Cruz Formation, Bajo de San Julian, Santa Cruz Province, Argentina: figs. 17-19, ₹ LV, OS 12128; fig. 17, int. lat.; fig. 18, central muscle scars (approx. x 380); fig. 19, ext. lat. 


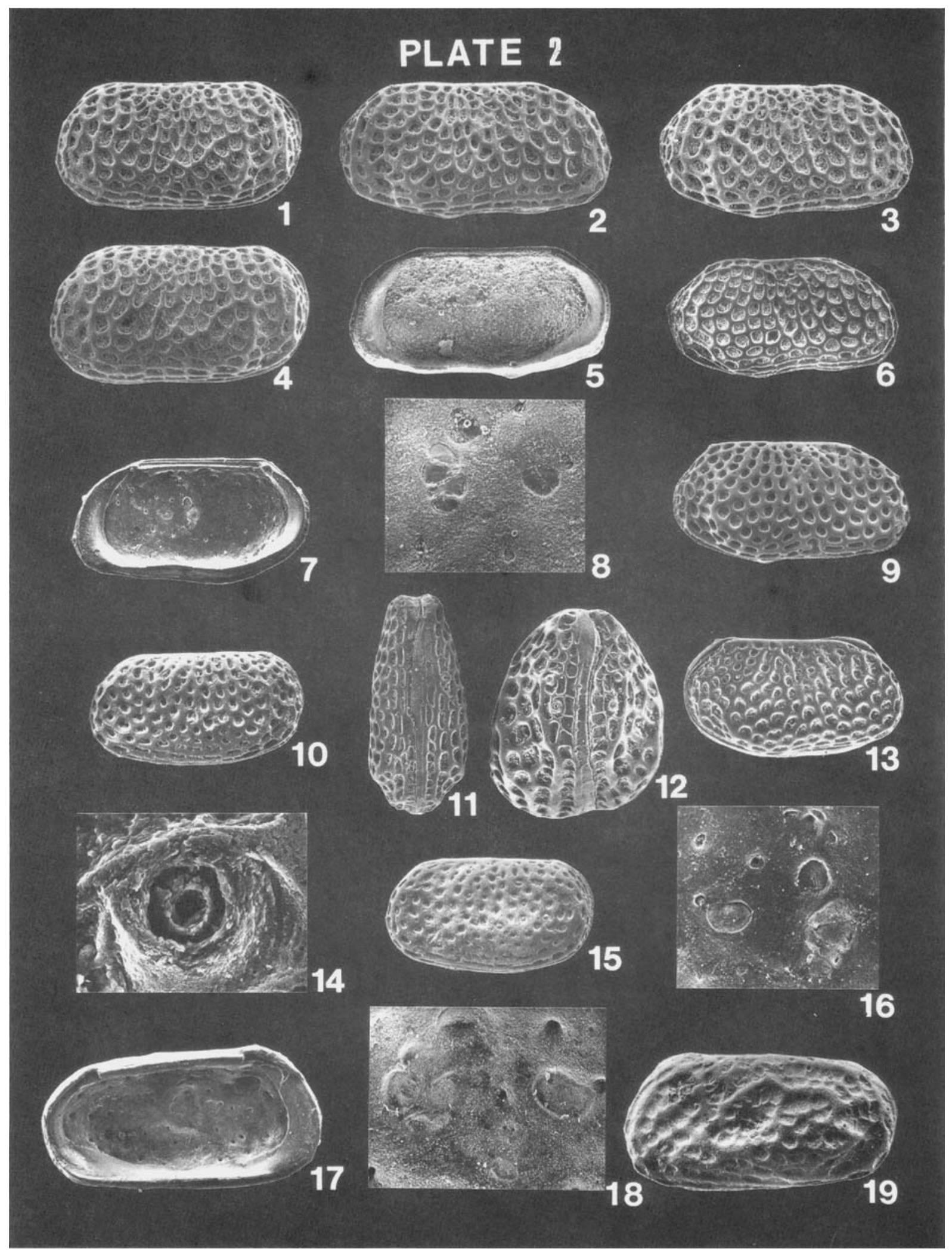


The elevated areas of the reticulum are relatively wide and this feature imparts a celated appearance to the species. The ornamental features on most of the valves are vertically aligned and radiate from the mid-dorsal region; around the free margins it parallels the margin, particularly ventrally where the fossae become elongate parallel to the long axis of the valve. In the right valve a distinct ventrolateral sub-alar ridge is developed posteriorly. Normal pore canals rather few and wellspaced; pores apparently simple and opening on the elevations where they are either flush with the surface or surrounded by elevated lips. Two large and complex pore conuli occur at a little distance from the posterior margin, each pore of which contains a tube-like cylindrical structure. Two similar but less prominent and less complex pore conuli occur anteriorly, adjacent to the margin. Inner lamella is of medium width; widest at the end margins where narrow crescentic vestibules occur. Selvage strong, broad and subperipheral. Radial pore canals not seen. Hinge lophodont with, in the right valve, two smooth knob-like terminal teeth connected by a broad smooth groove above which is a narrow "gutter"like accommodation groove. Adductor muscle scars situated medianly and comprising a subvertical row of 4 closely adjacent and interlocking scars of which the second scar from dorsal forms an isosceles triangle. Immediately anterodorsal to the adductors is a deep subcircular fulcral point. The frontal scar is large and reniform. Sexually dimorphic; males more elongate than females.

$\begin{array}{cll}\text { Dimensions. (mm) } & \text { Length } & \text { Height } \\ \text { Holotype of RV, OS 12123 } & 0.46 & 0.23 \\ \text { Paratype \& LV, OS 12124 } & 0.41 & 0.22 \\ \text { Paratype \& C, OS 12125 } & 0.42 & 0.22\end{array}$

The LV paratype is from locality 1 of Wouters and the carapace is from his locality 4 . See "Remarks" below.

Remarks. This species differs from other members of the genus in the shape of its anterior margin and the wide smooth nature of its costae. It is the only European species to possess a very pronounced posterior cardinal angle in the right valve. $R$. woutersi is thought to be ancestral to $R$. enigmatica and these two species contain morphological similarities, particularly with respect to the overall expression of their ornament. $R$. enigmatica is considerably larger, however, and has narrow and more radiate ribs. Neither species seems closely related to the Pacific species. Rockallia sp. from the Miocene of Germany is very similar and possibly derived from $R$. woutersi. Both these species seem to be restricted to Continental Europe and to have inhabited deeper shelf, rather than bathyal and abyssal environments.

Distribution. The species ranges from the Rupelian (M. Oligocene) to the Upper Miocene and has been found in northern Germany, Denmark and the Netherlands. It has been found by Wouters at the following localities:
1. Stemerdink farmyard at Brinkheurne, Winterswÿk, Netherlands. Boring 41E. 4-566, depth 5.5-6.0 m. Stratotype of the Stemerdink Bed, Aalton Member, Miocene.

2. Hand auger boring in the Mumbeckerbach at Klausenhof near Dingden, N.W. Germany; depths 3.5-3.8 m. and 2.5-2.8 m. Dingdener Schichten, Miocene.

3. Deep boring at Ratekau, N.W. Germany. $219.0 \mathrm{~m}$. Upper Oligocene. See Boekschoten, 1969, table 22.

4. Winterswÿk, Holland. "Devlyt" Clay pit. Base of the stratotype of the Winterswÿk Member, Rupelian.

5. Winterswÿk, Holland. "Stemordinkbrug", right bank of the Slinge, near Stemerdink farm, Brinkheurne. Stemerdink Bed, Aalten Member, Middle Miocene.

6. Deep boring at Vaale (W. Germany). Depth 263264 m. "Septarienton", Rupelian (See Boekschoten, 1969).

Uffenorde has found the species at the following localities in N.W. Germany:

1. Boring, Stade A 14, 174-177 m. Hemmoor "Stage", Lower Miocene.

2. Hoerstgen Schacht 4, $124.7 \mathrm{~m}$. Asterigerina guerichi guerichi Bed, Lower Chattian, Upper Oligocene.

3. Boring, Wursterheide, 352.8-353.0 m. Cibicides ungerianus Bed, "Rupelian 4", Middle Oligocene.

4. Boring, Wingst AB 14, 223.7-228 m. Hemmoor "Stage", Lower Miocene.

Lieberkind (1977, p. 189, pl. 9, fig. 5-6; pl. 21, fig. 1-2. text-fig. 78a-b, unpublished) described and figured specimens of $R$. woutersi under Loxoconcha sphenoides Lienenklaus 1905. Mrs. Lieberkind kindly placed her collection at the disposal of one of the authors (H.U.) for comparative studies.

Lieberkind mentioned the following localities in Denmark:

1. Boring Viborg 1, "AD typestyk" 123(?) Søvind Marl. Upper Eocene (?)

2. Boring Viborg 1, "AD typestyk" 101, 107, 111 Viborg Clay. Middle Oligocene.

Boring Viborg 1, "AD typestyk" 31. Grat. Clay. Upper Oligocene.

2. Grunfør brickworks, sample 17403. 17406. Viborg clay. Middle Oligocene.

3. Faarup brickworks, sample 23,0373. 1340, Grat Clay. Upper Oligocene.

4. Røgle Klint, sample 2014. Sort Clay. Upper Oligocene.

Rockallia sp.

(Pl. 2, fig. 15)

1980 Rockallia sp. 2 Uffenorde, table 1, p. 309, fig. 3, p. 313.

1981 Rockallia sp. 2 Uffenorde, text -fig. 2, p. 110. 
Material. 2 adult left valves.

Diagnosis. A very small and imperfectly known species of Rockallia characterized by rather rounded end margins and by a reticulum with small circular to oval fossae and wide interpunctate areas, the product of fairly advanced celation. Internal details as for genus.

\begin{tabular}{|c|c|}
\hline Dimensions. (mm) & Length \\
\hline \& LV OS 12126 & 0.395 \\
\hline \& LV OS 12127 & 0.40 \\
\hline
\end{tabular}

Distribution. Known only from boreholes in N.W. Germany, notably that of no. 4 above, Upper Miocene. Remarks. This new species is left in open nomenclature due to the paucity of the material. It seems to be most closely related to and possibly derived from $R$. woutersi.

\section{ACKNOWLEDGEMENTS}

Harlow, Downing and Kesler wish to acknowledge N.E.R.C. for the studentships they held during their association with this study. We jointly wish to acknowledge the assistance we have received from Dr. J.E. Whittaker, Messrs. P. Smith, M. Ayress, H. Williams, W. Edwards, A. Thawley and Mrs. C. Barnicoat, Miss E. Dainty and Mrs. M. Mayes. Uffenorde wishes to thank Mrs. Lieberkind (Geological Survey of Denmark) who kindly allowed him to examine her collection. Financial support was provided by the Deutsche Forschungsgemeinschaft Grant no. Gr. 264/3.

\section{REFERENCES}

Boekschoten, G.J. 1969. Fossilführung und stratigraphie des Oligo-Miozäns von fünf norddeutschen Bohrungen. Meyniana, Kiel, 19, 1-77.

Ducasse, O. \& J.P. Peypouquet. 1979. Cenozoic Ostracodes: their importance for bathymetry, hydrology and biogeography. Initial Reports of the Deep Sea Drilling Project. 48, 343-363, pls. 1-5.

Initial Reports of the Deep Dea Drilling Project. Volumes. 2, (1), 1971, 6, 1971; 21, 1973; 29, 1975; 30, 1975.

Lieberkind, K. 1977. Ostracodstratigrafi i фverste Eocaen og Oligocaen i Danmark. Belyst ud fra Viborg 1. boringen og enkelte daglokaliteter. Eksamensopgave, 1-257 (Univ. Copenhagen, unpub.).

Uffenorde, H. 1980. Über die Ostracodenverteilung im Miozän des nördlichen Niedersachsen (N.W. Deutschland). Neues Jb. Geol. Paläont. Mh., Stuttgart, 5, 303-320.

Uffenorde, H. 1981. Ostracoden aus dem Oberoligozän und Miozän des unteren Elbe-Gebietes (Niedersachsen und Hamburg, N.W.-deutsches Tertiäbecken). Palaeontographica, Abt. A 172 (4-6), 103-198.

Whatley, R.C., P. Frame \& J.E. Whittaker, 1978. On Rockallia enigmatica Whatley, Frame \& Whittaker gen. et. sp. nov. Stereo-Atlas of Ostracod Shells, 5 (24), 137-144. 